Edu Sciences J. Vol. 1, No. 1. March 2020, 63-69

\title{
UTILIZATION OF TOFU AND SAGO PULP AS ORGANIC LIQUID FERTILIZER AND ITS APPLICATION TO MUSTARD PLANT
}

\author{
Sunarti* and Romelos Untailawan** \\ Chemistry Education Program Faculty of Teacher Training and Education, \\ Pattimura University
}

\begin{abstract}
Tofu waste and sago pulp are waste that has the potential to pollute the environment because it creates unpleasant aesthetic odors. On the other hand, this second waste still contains nutrients, especially macro nutrients, so it can be used as a material for making liquid organic fertilizer. In this study, both materials were used as liquid organic fertilizer through the fermentation process with the addition of EM4 liquid and the determination of nitrogen and phosphorus elements by the Kjheldal method and spectrophotometry. Based on the research results obtained Nitrogen levels in tofu waste, sago pulp and liquid organic fertilizer in a row: $2.2558 \% ; 0.4236 \%$ and $0.0382 \%$. While the phosphorus content in a row: $0.024 \% ; 0.014 \%$; and $0.012 \%$. The results of the application of liquid organic fertilizer on mustard plants gave a tendency to increase plant height, leaf length, leaf width of mustard plants, but there was no addition of leaf blade for 14 days after planting.
\end{abstract}

Keywords: Tofu waste, Sago Pulp, Liquid Organic Fertilizer, Nitrogen, Phosphorus

\section{Introduction}

Sago waste is a byproduct of solid starch processing industry. According to research (Tampoebolon., 2009) Sago waste contains 53.20\% Carbon, $0.13 \%$ Nitrogen, $0.08 \%$ Potassium, 0.04\% Calcium, 0.02 ppm Magnesium, 205.30 ppm Iron, Copper 2, 10 ppm, Zinc $5.20 \mathrm{ppm}$, Manganese $100.20 \mathrm{ppm}$, water 50.19\%. Meanwhile, tofu waste is the residue of tofu that is produced during the process of making tofu in the form of liquid and solid waste. The content of chemical elements in $100 \mathrm{~mL}$ of tofu wastewater is 4.9 grams of water, 17.4 grams of protein, $19 \mathrm{mg}$ of calcium, $29 \mathrm{mg}$ of phosphorus and $4 \mathrm{mg}$ of iron.

Considering the high content of organic matter and minerals in sago and tofu waste, these organic materials can be recycled by microbes, so that it becomes a potential nutrient to increase plant growth by utilizing it to be a liquid organic fertilizer (Bilallian, et al., 2016: 1). Makiyah Research (2013) about the analysis of N, P, and K levels in liquid organic fertilizer of tofu waste with the addition of Mexican sun plants the highest N level of $0.0732 \%$ was obtained from a 4 day fermentation sample with $9 \mathrm{~g}$ Mexican sun powder composition and tofu waste fertilizer $200 \mathrm{ml}$ of liquid. Likewise, the highest $\mathrm{P}$ and $\mathrm{K}$ are $0.08406 \%$ and $0.7189 \%$ obtained from a 4 day fermentation sample with the addition of $9 \mathrm{~g}$ Mexican sun powder. According to research Sugiarti (2004) plants that are given Mexican sun fertilizer grow well even almost the same as plants that are given inorganic fertilizer. This is evidenced by the width of the leaves in plants that are given Mexican sun fertilizer is not much different from plants

Received October $15^{\text {th }} 2019$, Revision Februrry $12^{\text {th }} 2020$, Accepted for publication February $18^{\text {th }} 2020$. Copyright (C) 2020 Published by FKIP - Unpatti, ISSN 2721-3110 
that are given inorganic fertilizers. Based on the foregoing, this research will combine the two wastes to produce liquid organic fertilizer which is useful to overcome the problem of environmental pollution while at the same time overcome the problem for farmers who complain about the high cost of inorganic synthetic fertilizer.

\section{Method}

Tool

Sample container, glassware, Spatula, filter paper W 41, analytical balance, kjeldahl flask, distillator unit, UV-Visible spectrophotometer

\section{Material}

Tofu waste, sago waste, aquades, EM4, selenium mixture, 98\% concentrated $\mathrm{H}_{2} \mathrm{SO}_{\mathrm{r}}$, $\mathrm{NaOH}$, boric acid, conway indicator, 37\% concentrated $\mathrm{HCl}$, concentrated $\mathrm{HNO} 365 \%, 70 \%$ concentrated $\mathrm{HClO}_{4}$, ammonium molibdat, potassium antimoniltartrate, ascorbic acid, and standard solution of P $1000 \mathrm{ppm}$.

\section{Research procedure}

\section{a. Liquid Organic Fertilizer Manufacturing}

Mixing tofu liquid waste, tofu solid waste, and sago waste waste in a ratio of 1: 1: 1 . The mixture is put in a closed container and added EM4 $50 \mathrm{~mL}$, stirred until homogeneous and evenly mixed then the container is tightly closed until the air cannot enter and then fermented for 4 days.

\section{b. Determination of Nitrogen Nutrients}

Take a sample of $1 \mathrm{~mL}$ and put it in a $100 \mathrm{~mL}$ Kjehdahl flask. Add 0.25 gram selenium mixture and $3 \mathrm{~mL} \mathrm{H}_{2} \mathrm{SO}_{4} 0.05 \mathrm{~N}$ to be mixed until evenly mixed and allowed to stand for 2 hours. Destined to perfection with a gradual temperature of $150^{\circ} \mathrm{C}$ until finally a maximum temperature of $350^{\circ} \mathrm{C}$ and obtained clear liquid ( 3 hours). After chilling, dilute with a little distilled water so it does not crystallize. Quantitatively transferred the solution into a $250 \mathrm{~mL}$ distilled boiling flask, plus distilled water to half the volume of boiling flask and a little boiling stone. Plus $10 \mathrm{~mL}$ of $40 \% \mathrm{NaOH}$. Prepare a distillate container, which is $10 \mathrm{~mL}$ of $1 \%$ boric acid in a $100 \mathrm{~mL}$ erlenmeyer added with 3 drops of the conway indicator, and is stopped when the liquid in the erlenmeyer has reached about $75 \mathrm{~mL}$. The solvent is titrated with $0.15 \mathrm{~N} \mathrm{HCl}$ solution until the solution turns red

\section{c. Determination of Phosporus Nutrient Sample Destruction}

Take $5 \mathrm{~mL}$ of sample into the Kjeldahl flask, plus $5 \mathrm{~mL}$ of $\mathrm{HNO}_{3}$ and $0.5 \mathrm{~mL}$ of $\mathrm{HClO}_{4}$, shake and leave it overnight. Heated starting with a temperature of $100^{\circ} \mathrm{C}$, after the yellow steam runs out the temperature is raised to $200^{\circ} \mathrm{C}$. Destruction is terminated when white steam and liquid in the flask are left around $0.5 \mathrm{~mL}$ cooled and diluted with distilled water and the volume is adjusted to $50 \mathrm{~mL}$, shake until homogeneous and left overnight or filtered with filter paper W-41 for clear extracts (A extract)

Received October $15^{\text {th }} 2019$, Revision Februrry $12^{\text {th }} 2020$, Accepted for publication February $18^{\text {th }} 2020$. Copyright (C) 2020 Published by FKIP - Unpatti, ISSN 2721-3110 


\section{Making Color Generating ReagentsConcentrated reagents}

Weighed 12 grams $\left(\mathrm{NH}_{4}\right) \quad 6 \mathrm{Mo}_{7} \mathrm{O}_{24} \cdot 4 \mathrm{H}_{2} \mathrm{O}$ plus 0.275 grams of potassium antimoniltartrate plus $140 \mathrm{~mL} \mathrm{H}_{2} \mathrm{SO}_{4}$ pa then diluted with distilled water up to $1000 \mathrm{~mL}$.

Dilute reagents; 0.53 grams of ascorbic acid plus $50 \mathrm{~mL}$ of concentrated reagents made into $500 \mathrm{~mL}$ with ion free water (Eviati and Sulaeman, 2009)

\section{Determination of the maximum wavelength}

A total of $1 \mathrm{~mL}$ of $8 \mathrm{ppm}$ standard phosphorus solution was put into a $10 \mathrm{~mL}$ volumetric flask and $9 \mathrm{~mL}$ of reagent solution was added until the boundary mark was then allowed to stand for 15 minutes. The solution is put into a UV-Vis cuvette and its absorbance is measured at wavelengths between $650-750 \mathrm{~nm}$.

\section{Making a calibration curve}

Prepare 6 pieces of $25 \mathrm{~mL}$ volumetric flask for pumpkin number 1 filled in blanks while flask 2 to 6 filled with standard solution of 0.25 phosphorus; $0.50 ; 0.75 ; 1,0 ;$ and 1.25 ppm each as much as $1 \mathrm{~mL}$ and then added by reagents (concentrated reagents and dilute reagents) as much as $9 \mathrm{~mL}$ after that it is allowed to stand for 15 minutes. The solution is inserted into the cuvette and measured its absorbance at the maximum wavelength.

\section{Determination of $P$ levels in the sample}

Take $1 \mathrm{~mL}$ of the extract from destruction (extract A) put into a $25 \mathrm{~mL}$ volumetric flask and then add distilled water to the boundary mark then shake until homogeneous (extract B). Pipette $1 \mathrm{~mL}$ extract B into a $25 \mathrm{~mL}$ volume flask, as well as each standard P series plus 9 $\mathrm{mL}$ color generating reagents into each sample and standard series, shaken until homogeneous. Left for 15 minutes, then measured by UV-Vis at a wavelength of $713 \mathrm{~nm}$.

\section{Results and Discussion}

The process of decomposition of organic N, especially protein, involves two processes, namely ammonification and nitrification. Ammonification is a process where organic $\mathrm{N}$ is converted to ammonium through the process of proteolysis and aminofication. On going reactions (Nitihadiprawiro, 1999)

$$
\begin{aligned}
N_{\text {Organik }} & \text { proteolisis } \underset{\mathrm{RNH}_{2}}{\longrightarrow}+\mathrm{CO}_{2}+\text { hasil lain }+ \text { Energi } \\
\mathrm{RNH}_{2} & +\underset{\mathrm{H}_{2} \mathrm{O} \text { Aminofikasi }}{\longrightarrow} \mathrm{NH}_{4}^{+}+\mathrm{ROH}+\text { Energi }
\end{aligned}
$$

If oxygen is available and other environmental factors support it, $\mathrm{NH}_{4}{ }^{+}$will be easily oxidized to $\mathrm{NO}_{2}{ }^{-}$and $\mathrm{NO}_{3}{ }^{-}$. This oxidation is called nitritation and nitratation

$$
\mathrm{NH}_{4}^{+}+\mathrm{O}_{2} \quad \text { Nitrasamonas } \underset{\mathrm{N}}{\longrightarrow} \mathrm{O}_{2}^{-}+\mathrm{H}_{2} \mathrm{O}+\mathrm{H}+\text { Energi }
$$

Received October $15^{\text {th }} 2019$, Revision Februrry $12^{\text {th }} 2020$, Accepted for publication February $18^{\text {th }} 2020$. Copyright (C) 2020 Published by FKIP - Unpatti, ISSN 2721-3110 


$$
\mathrm{NO}_{2}^{-}+\mathrm{O}_{2} \stackrel{\text { Nitrobacter }}{\longrightarrow} \mathrm{NO}_{3}^{-}+\text {Energ }
$$

According to Hayland (2005), microbial conversion to phosphorus is called mineralization. Conversion that occurs is decomposing organic $\mathrm{P}$ (for example: nucleic acids, phospholipids, and inisitol phosphates) to $\mathrm{H}_{2} \mathrm{PO}_{4}^{-}$, or $\mathrm{HPO}_{4}{ }^{2-}$, which is $\mathrm{P}$ dissolved for plants or referred to as orthophosphate.

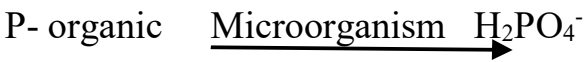

Physically the resulting organic liquid fertilizer ( LOF) is brownish yellow and smells like a tape odor. The emergence of a pungent odor like the smell of tape indicates the formation of organic acids such as lactic acid, acetic acid, and pyruvic acid derived from decomposition of organic matter (Aditya and Qoidani, 2017). Based on the results of the study obtained levels of nitrogen respectively for tofu waste, sago pulp, and 4-day fermentation POC are shown in the table below

Table 1. Levels of Nitrogen tofu waste, sago pulp and POC

\begin{tabular}{ccc}
\hline N level of tofu pulp (\%) & N level of sago pulp (\%) & N LOF level (\%) \\
\hline 2,2558 & 0,4236 & 0,0382 \\
\hline
\end{tabular}

From the results of the analysis of liquid organic fertilizer produced does not meet the standards set by the Minister of Agriculture No. 70, because the total nitrogen content is still far from the standard that is $3 \%-6 \%$. This is due to insufficient fermentation time for decomposition of organic material in liquid organic fertilizer. According to Hanafiah (2004), that in the process of mineralization of nitrogen compounds occurs in 3 stages, namely: amination in the ammonia gas resulting from mineralization if not immediately ammonified or not used by microorganisms will immediately evaporate into the air. Ammonification, that is, most of the ammonia will change to $\mathrm{NH}_{4}{ }^{+}$due to a strong electron bonding process with $\mathrm{H}^{+}$ ions, nitrification where nitrate is used by anaerobic organisms for its respiration as a substitute for oxygen.

Phase analysis of phosphorus content is by destruction which aims to oxidize organic compounds contained in liquid organic fertilizer samples using concentrated nitric acid and concentrated $\mathrm{HClO}_{4}$. Then the sample is destructed until the sample is only $0.5 \mathrm{~mL}$ remaining. At the beginning of the destruction, brownish-colored gas occurs and gives rise to a very strong odor. Then after the remaining solution is $0.5 \mathrm{~mL}$, it is cooled and allowed to stand and diluted with distilled water to mark the mark. Quantitative measurement of phosphorus levels with a UV-Vis spectrophotometer using a mixture of ammonium molybdate, sulfuric acid, ascorbic acid, and potassium antimoniltartrate (color generating reagents) and will cause a blue color in the solution. In an acidic medium, orthophosphate forms a yellow complex with molybdate. In the presence of ascorbic acid and antimoniltartrate, phosphomolybdate complexes are formed in blue. Antimoniltartrate is added to complete the reduction of the yellow phosphomolybdenum complex to the blue phosphomolybdenum complex. Antimoniltartrates increase the intensity of the color blue and cause more sensitive measurements of absorbance.

Received October $15^{\text {th }} 2019$, Revision Februrry $12^{\text {th }} 2020$, Accepted for publication February $18^{\text {th }} 2020$. Copyright (C) 2020 Published by FKIP - Unpatti, ISSN 2721-3110 
Ascorbic acid functions as a reducing agent that causes the formation of molybdenum (V). The reactions that occur are:

$$
\begin{gathered}
\mathrm{PO}_{4}^{3-}+12 \mathrm{MoO}_{4}^{2-}+27 \mathrm{H}^{+} \rightarrow \mathrm{H}_{7}\left[\mathrm{P}\left(\mathrm{Mo}_{2} \mathrm{O}_{7}\right) 6\right]+10 \mathrm{H}_{2} \mathrm{O} \\
\mathrm{H}_{7}\left[\mathrm{P}\left(\mathrm{Mo}_{2} \mathrm{O}_{7}\right) 6\right]+\text { Vitamin } \mathrm{C} \rightarrow \text { blue molybdate } \\
\left(\mathrm{NH}_{4}\right) 3 \mathrm{PO}_{4} \cdot \mathrm{MoO}_{3} \mathrm{n}+\mathrm{Sn}^{2+} \rightarrow \mathrm{Mo}^{5+}+\mathrm{Sn}^{4+}(\text { Makiyah, 2013) }
\end{gathered}
$$

Table 2. Levels of phosphorus tofu pulp, sago pulp, and LOF

\begin{tabular}{ccc}
\hline P level of tofu pulp ( \%) & P level of sago pulp ( \% ) & P level of LOF ( \% ) \\
\hline 0,024 & 0,014 & 0,012 \\
\hline
\end{tabular}

Based on these data it can be seen that the levels of phosphorus in liquid organic fertilizer are smaller than in tofu waste or sago pulp. This is due to several factors, namely: (1) imperfect fermentation. (2) The imbalance factor of the energy source is $100 \mathrm{~mL}$ liquid sugar water added during fermentation compared to the weight of the sample of tofu waste and sago pulp weighing $500 \mathrm{~g}$ each, so that bacteria convert it into methane gas without converting it to macronutrients (Marlina, 2016 ) and (3) The nitrogen factor will also affect the phosphorus content.

Measurement of plant height, leaf length, leaf width and number of leaf strands was carried out on day 7 after planting in polyback. In general there was an increase in height, leaf length, width, but the number of leaf strands did not change much on the 14th day. This is presumably because the root development has increased along with the longer planting time. The results of measurement of the physical parameters of mustard plants are presented in table 3

Table 3. Measurement of the physical parameters of mustard plants on the 7th day of planting.

\begin{tabular}{lll}
\hline \multicolumn{1}{c}{ Parameters } & \multicolumn{2}{c}{ Treatment } \\
\cline { 2 - 3 } & A & B \\
\hline Plant height $(\mathrm{cm})$ & 3 & 5 \\
Leaf length $(\mathrm{cm})$ & 2 & 4 \\
Leaf width $(\mathrm{cm})$ & 2 & 3 \\
Number of leaves (strands) & 2 & 2 \\
\hline A = Control (mustard without fertilization) & \\
B = Mustard with fertilization & &
\end{tabular}

Table 4. Measurement of physical parameters of mustard plants on the 14th day of planting

\begin{tabular}{lll}
\hline \multirow{2}{*}{ Parameters } & \multicolumn{2}{c}{ Treatment } \\
\cline { 2 - 3 } & A & B \\
\hline Plant height $(\mathrm{cm})$ & 4 & 8 \\
Leaf length $(\mathrm{cm})$ & 2 & 6 \\
\hline
\end{tabular}

Received October $15^{\text {th }} 2019$, Revision Februrry $12^{\text {th }} 2020$, Accepted for publication February $18^{\text {th }} 2020$. Copyright (C) 2020 Published by FKIP - Unpatti, ISSN 2721-3110 


\begin{tabular}{lll}
\hline Leaf width (cm) & 2 & 4 \\
Number of leaves (strands) & 2 & 2 \\
\hline
\end{tabular}

From tables 3 and 4 it can be seen that there is a tendency for an increase in plant height, leaf length, leaf width, and number of leaves of mustard plants compared to controls. This is thought to be a direct influence of the application of liquid organic fertilizer on mustard plants. According to Novisan (2002) that nitrogen is needed in vegetative growth, such as the formation of shoots, or the development of stems and leaves. Phosphorus can stimulate the initial growth of seedlings, stimulate the growth of flowers, fruit and seeds.

\section{Conclusion}

Based on the results of the study it can be summarized as follows:

a. Liquid organic fertilizer can be made from tofu dregs and sago dregs, although the levels do not meet the Permentan standard No.70 of 2011.

b. Nitrogen content in tofu waste, sago pulp, and liquid organic fertilizer respectively: $2.2558 \% ; 0.4236 \%$; and $0.0382 \%$, while the phosphorus content respectively: $0.024 \%$; $0.014 \% ; 0.012 \% .3$. Provision of liquid organic pepper has a tendency to increase plant height, leaf length, leaf width of mustard plants, while the number of leaves does not change for 14 days after planting.

\section{References}

Asmoro, Yuliadi. (2008). Utilization of Tofu Waste for Yield of Brassicides (Brassica chinensis). Graduate program. Sebelas Maret University Surakarta.

Bilallian, H. I., et al. (2016). Utilization of Tofu Liquid Waste as Nutrition Enhancer for the Growth of Segon Seedlings (Falcataria moluccana). Bogor: Faculty of Mathematics and Natural Sciences Pakuan University.

Clark, B. J. (1993). UV Spectroscopy Techniques Instrumentations, Data Handling. London: Chapman \& Hall.

Day, R. A and Underwood, A. L (1986). Quantitative Chemical Analysis. Fifth Edition. Jakarta: Erlangga.

Desiana, C., et al. (2013). Effects of Organic Cow Urine Fertilizer and Tofu Waste on Growth of Cocoa Seedlings (Theobroma cacao L.). Journal of Tropical Agriculture. 1 (1): $113-119$.

Eviati \& Sulaeman. 2009. Chemical Analysis of Soil, Plants, Water and Fertilizers. Bogor: Agricultural Research and Development Agency Ministry of Agriculture.

Hadisuwito, S. (2012). Make Liquid Compost Fertilizer. Third printing. Jakarta: Agromedia Reader.Hendayana, S. (1994). Analytical Chemistry Instruments. Semarang: IKIP Semarang Press.Khopkar, S. M. (1990). Basic Concepts of Analytical Chemistry. Jakarta: Universitas Indonesia Press.

Makiyah, Mujiatul. (2013). Analysis of N, P, and K Levels in Tofu Liquid Waste Fertilizer with the Addition of Mexican Sun Plant (Thitonia diversivolia). Thesis. Faculty of Math and Science. Semarang State University.

Received October $15^{\text {th }} 2019$, Revision Februrry $12^{\text {th }} 2020$, Accepted for publication February $18^{\text {th }} 2020$. Copyright (C) 2020 Published by FKIP - Unpatti, ISSN 2721-3110 
Edu Sciences J. Vol. 1, No. 1. March 2020, 63-69

Netty, D., et al. (2015). Comparison Between Provision of Tofu Liquid Waste and Stale Tea Waste Against Plant Growth Rate (Spathiphyllum Floribumdum). Proceedings of the Biology Education Seminar.

Ngaisah, Siti. (2012). Effect of Combination of Tofu Liquid Waste and Household Organic Waste Compost on Growth and Yield of Kailan (Brassica oleracea Var. Achepala). Thesis. Faculty of Science and Technology. UIN Maulana Malik Ibrahim Malang.

Nurlila, R. U. (2009). Vegetative growth, N-Total and B-carotene content of mustard (Brassica juncea L.) from compost treatment and combination of tofu liquid waste and sago liquid waste as organic fertilizer. Thesis UGM Postgraduate Program Yogyakarta: Gadjah Mada University.

Novisan, 2002., Effective Fertilization Guidelines, AgroMedia ReaderPerdana, D. A., Ebrianto, L.A. \& Sari, I. T. (2013). The Use of Envirosolve Starters and Biodextrin for Producing Biogas from Tofu Dregs Raw Material. Journal of Chemical Engineering. 1 (19): 16-20

Rahmah, N. F. (2011). Study on the utilization of tofu liquid waste for liquid fertilizer of plants (case study of kenjeran tofu factory). Accessed from http: //ITSUndergraduate17312Abstract id.pdf.

Tampoebolon, B. I. M. (2009). Study of the Difference between Levels and Curing Period of Sago Ampa Fermentation with Aspergillus niger Against the Contents of 35 Crude Proteins and Crude Fiber. National Seminar on Resurrection of Livestock: 235-243.

Wahida and Amelia. (2015). Utilization of Sago Lees as Compost Base Material in Several Doses of Mixing with Cow Manure. Agricola Journal. 5 (1): 1-8. Yahya, Firman. (2016). Analysis of Carbon, Nitrogen, Phosphorus, and Potassium Levels from Rotten Tempe in Setia Budi Market, Medan. Thesis. Faculty of Math and Science. University of Northern Sumatra

Received October $15^{\text {th }} 2019$, Revision Februrry $12^{\text {th }} 2020$, Accepted for publication February $18^{\text {th }} 2020$. Copyright (C) 2020 Published by FKIP - Unpatti, ISSN 2721-3110 